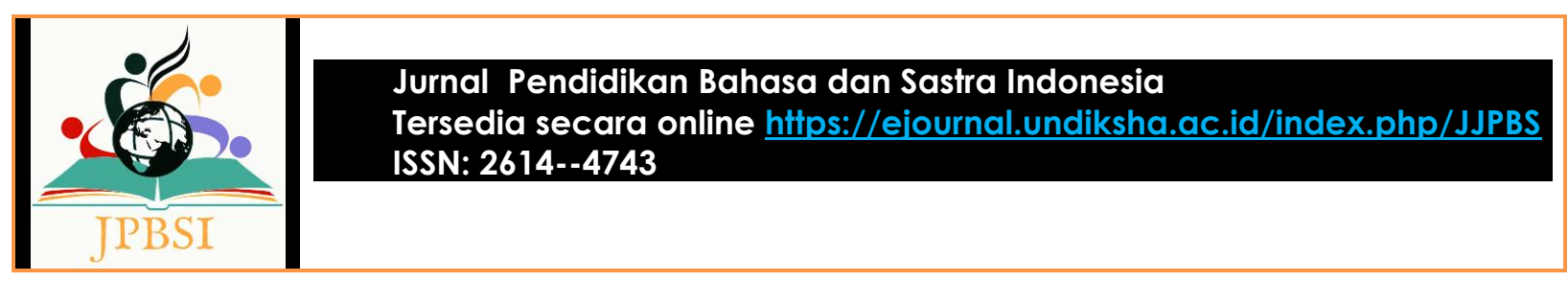

\title{
TRANSFORMASI NOVEL TUJUH MISI RAHASIA SOPHIE KARYA ADITIA YUDIS DALAM FILM TUJUH MISI RAHASIA SOPHIE KARYA SUTRADARA BILLY CHRISTIAN KAJIAN SASTRA BANDINGAN: PENDEKATAN PSIKOLOGI SASTRA
}

\author{
Aulia Rachmawati Widi Hartati ${ }^{1}$, Euis Kurnia ${ }^{2}$, Dian Hartati ${ }^{3}$ \\ 1,2,3 Program Studi Pendidikan Bahasa dan Sastra Indonesia, Universitas Singaperbangsa Karawang \\ Karawang, Indonesia
}

\begin{abstract}
Surel:1710631080036@student.unsika.ac.id',1710631080056@student.unsika.ac.id², dian.hartati@fkip.unsika.ac.id ${ }^{3}$
\end{abstract}

\begin{tabular}{|c|c|}
\hline \multicolumn{2}{|r|}{ Abstrak } \\
\hline $\begin{array}{l}\text { Kata Kunci: } \\
\text { Karakter Tokoh; } \\
\text { Sastra Bandingan; } \\
\text { Tujuh Misi Rahasia } \\
\text { Sophie. }\end{array}$ & $\begin{array}{l}\text { Penelitian ini dilakukan untuk mengetahui, perbedaan struktur pada alur, tokoh, dan latar } \\
\text { novel dan film, proses transformasi cerita novel ke dalam film Tujuh Misi Rahasia } \\
\text { Sophie, karakteristik psikologi tokoh yang ada dalam novel dan film Tujuh Misi Rahasia } \\
\text { Sophie. Penelitian ini menggunakan metode deskriptif kualitatif dan pendekatan } \\
\text { psikologi sastra. Tujuan penelitian adalah mendeskripsikan perubahan alur, latar, dan } \\
\text { tokoh yang terjadi dalam novel dan film Tujuh Misi Rahasia Sophie. Data penelitian } \\
\text { berupa kata, penggalan kalimat, uraian kalimat, dialog dalam novel dan film Tujuh Misi } \\
\text { Rahasia Sophie. Teknik pengumpulan data menggunakan teknik simak dan catat dan } \\
\text { teknik dokumentasi. Hasil penelitian menunjukkan bahwa, perbedaan struktur dalam } \\
\text { novel dan film Tujuh Misi Rahasia Sophie yaitu tema, alur dan latar. Alur novel dan film } \\
\text { memiliki perbedaan di antaranya, tokoh novel dan film terdapat penambahan tokoh, latar } \\
\text { waktu novel dan film memiliki persamaan, latar tempat novel terdapat lima belas tempat } \\
\text { dan latar tempat film terdapat tiga belas latar tempat, latar suasana dalam novel dan film } \\
\text { dominan senang dan sedih. Proses transformasi cerita novel dan film terjadi perubahan } \\
\text { variasi yang terjadi di awal cerita, tengah dan akhir cerita. Karakteristik psikologi tokoh } \\
\text { utama Sophie dalam novel dan film adalah memiliki kejiwaan sebal, marah, bahagia dan } \\
\text { sedih. }\end{array}$ \\
\hline \multicolumn{2}{|r|}{ Abstract } \\
\hline $\begin{array}{l}\text { Keywords: } \\
\text { characteristics, } \\
\text { comparative } \\
\text { literature, sophie's } \\
\text { seven secret } \\
\text { mission }\end{array}$ & $\begin{array}{l}\text { This research was conducted to determine the differences in the structure of the plot, } \\
\text { characters, and setting of the novel and the movie, the transformation process of the } \\
\text { novel into Sophie's Seven Secret Missions movie, the psychological characteristics of the } \\
\text { characters in Sophie's Seven Secret Missions novel and movie. This study uses a } \\
\text { qualitative descriptive method and a literary psychology approach. The purpose of this } \\
\text { research is to describe the changes in plot, setting, and characters that occur in Sophie's severen } \\
\text { Seven Secret Missions novels and movie. Research data in the form of words, sentence } \\
\text { fragments, sentence descriptions, dialogues in the novel and movie of Sophie's Seven } \\
\text { Secret Missions. Data collection techniques used listening and note-taking techniques } \\
\text { and documentation techniques. The results of the research showed that the differences } \\
\text { in structure in the novel and movie of Sophie's Seven Secret Missions are theme, plot } \\
\text { and setting. The plots of novels and movie have differences between them, in the novel } \\
\text { and movie characters have additional characters, the time setting of novels and movie } \\
\text { has similarities, the setting in which the novel has } 15 \text { places and the setting where the } \\
\text { movie has } 13 \text { places, the background of the atmosphere in the novel and the movie is } \\
\text { dominantly happy and sad. The process of transforming novels and movies into } \\
\text { variations occurs at the beginning, middle and end of the story. The psychological } \\
\text { characteristics of the main character Sophie in the novel and movie are having a mental } \\
\text { resentful, angry, happy and sad. }\end{array}$ \\
\hline
\end{tabular}




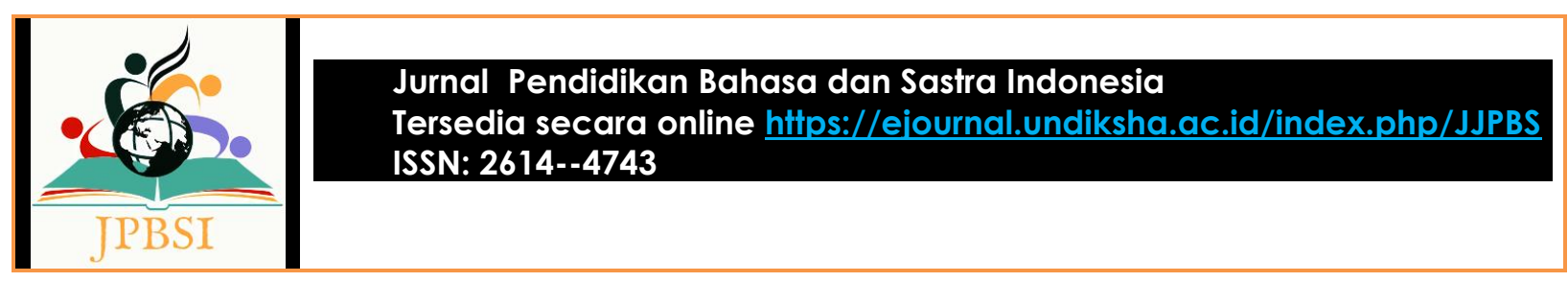

Diterima/direview/ 18 Juli 2021/ 13 Agustus 2021/ 30 September 2021 dipublikasi

\section{PENDAHULUAN}

Sastra merupakan penceritaan budaya dari suatu masyarakat. Melalui karya sastra kita dapat mengetahui budaya dari masyarakat tertentu. Karya sastra pun menjadi ruang dan waktu untuk merekam kejadian dari suatu tempat dan waktu tertentu. Karya sastra dapat tercipta dari seorang penulis yang menceritakan masalah kehidupan baik pribadi atau orang lain. Sastra dapat mempengaruhi dan berpengaruh pada masyarakat. Seorang penikmat karya sastra dapat menemukan nilai-nilai yang terkandung baik tersirat ataupun tidak tersirat seperti novel. Novel merupakan karangan berisi cerita yang mengandung unsur intrinsik dan unsur ekstrinsik.

Novel yang sukses diadaptasi menjadi film dan tayang di bioskop Indonesia seperti Dilan (2017), penulis novel adalah Pidi Baiq dan sutradara Fajar Bustomi, Ananta Prahadi (2018), penulis novel adalah Risa Sarawati dan sutradara Rizki Baiki, Hujan Bulan Juni (2017), penulis novel adalah Sapardi Djoko Damono dan sutradara Reni Nurcahyo Hestu Saputra, Danur (2017), penulis novel adalah Risa Saraswati dan sutradara Awi Suryadi, dan Sabtu Bersama Bapak (2016) penulis novel adalah Aditya Mulya dan Monty Tiwa. Film tersebut bisa di akses saat ini melalui aplikasi Viu, Netflix, WeTV, Vidio_id, Disney+Hotstar dan yang lainnya. Film yang mengangkat cerita dari novel mengalami perubahan baik dari segi latar, alur dan tokoh. Perubahan cerita novel menjadi film menarik untuk dikaji agar pembaca dan penonton mengetahui hal apa saja yang menjadi pembeda, sehingga dapat mengambil hal baik dan buruk pada bagian-bagian yang berubah antara novel dan film.

Menurut Darma (dalam Artayasa, dkk. 2017) Sastra bandingan lahir dari kesadaran bahwa sastra tidak tunggal, namun sastra itu plural serta semua sastra ada kesamaan-kesamaan dan perbedaanperbedaanya. Jadi, sastra bandingan adalah membandingkan karya satu dengan karya sastra yang lain dengan perbandingan sifat, bentuk, dan sebagainya. Perbandingan karya sastra dari novel ke film adalah hal kreatif, maka dengan adanya perbandingan ini pembaca akan dapat mengetahui atau keterlibatan perubahan bentuk dan struktur cerita.

Menurut KBBI (edisi 5: 2016), transformasi adalah perubahan rupa (bentuk, sifat, fungsi). Selanjutnya, menurut Nurgiyantoro (dalam Purnomo, dkk. 2018) Transformasi adalah perubahan suatu hal atau keadaan. Bentuk perubahan, ada kalanya berubah kata, kalimat, struktur, dan isi karya sastra (novel) itu sendiri. Transformasi bisa dikatakan, pemindahan atau pertukaran suatu bentuk ke bentuk lain, yang dapat menghilangkan, memindahkan menambah, atau mengganti unsur seperti transformasi novel ke film. Menurut Malida, (2009) Film yang diadaptasikan dari sebuah novel menimbulkan berbagai respon dari pembaca. Ada beberapa pembaca dengan respon positif yaitu merasa puas, setelah menonton film yang dialihwahanakan karena isi film sesuai dengan isi novel ataupun isi film sesuai dengan imaji pembaca dan ada pula respon negatif yaitu kekecewaan yang ditimbulkan karena tidak sesuai dengan imaji pembaca.

Menurut Minderop (dalam Erlina, 2016) Psikologi sastra adalah telaah karya sastra yang diyakini mencerminkan proses dan aktivitas kejiwaan. Jadi, psikologi sastra merupakan salah satu pendekatan dalam menelaah sebuah karya sastra dengan memfokuskan pada kejiwaan atau perilaku tokoh-tokoh didalamnya.

Penelitian relevan yang dilakukan oleh Pt. Agus Agus Artayasa, Gd. Artawan, IB. Sutresna yang berjudul Perbandingan Novel Laskar Pelangi Karya Andrea Hirata dengan Novel Dua Belas Pasang Mata Karya Sakae Tsuboi, Serta Kontribusinya Bagi Pembelajaran Sastra Di SMA. Tahun 2017 dari Universitas Pendidikan Ganesha. Penelitian ini membandingkan unsur intrinsik yang terdapat pada novel Laskar Pelangi Karya Andrea Hirata dengan Novel Dua Belas Pasang Mata karya Sakae Tsuboi. 


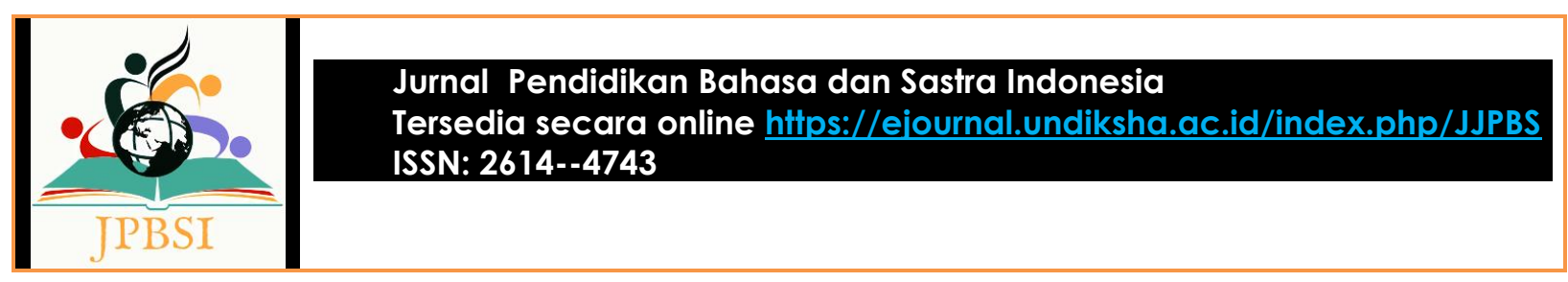

Sedangkan penelitian yang penulis lakukan adalah membandingkan karya sastra novel dan film dengan kajian sastra bandingan: pendekatan sosiologi sastra.

Novel Tujuh Misi Rahasia Sophie yang ditransformasikan menjadi film, menceritakan persahabatan Sophie dan Marko yang memiliki perbedaan namun tetap saling mendukung, saling bersama dan saling menghibur. Sophie memiliki sifat yang ceria, peduli dengan lingkungan, dan peduli dengan sesama, berbeda dengan Marko yang memiliki sifat cuek, tidak peduli dengan sekitarnya. Keunikan persahabatan ini Sophie dan Marko mampu mengobrol menggunakan sandi Morse. Sophie, memilik ide 7 Misi Rahasia Sophie yang ingin dilaksanakan dengan menyelesaikan misi-misi nya, melalui penampilan dirinya dalam video dengan tujuan menginspirasi, peduli sesama dan dengan begitu Sophie ingin merubah Marko menjadi orang yang lebih baik lagi dengan adanya 7 Misi Rahasia Sophie. Sophie, membuat video dengan sosial medianya bukan berisikan persoalan narsis atau eksis, tetapi video itu mengandung makna hidup didalamnya. Sehingga, pembaca atau penonton dapat mengambil pelajaran baik dari hal yang ditonton maupun dibaca.

Novel yang dibandingkan ke dalam bentuk film pasti akan mengalami perubahan. Penggunaan teknologi dapat dijadikan wahana untuk mengalih wahanakan dari suatu novel menjadi film, yang bermula menggunakan buku dan imajinasi dengan teknologi dapat mengubah menjadi adegan. Menurut Krevolin (dalam Mahanani, 2013) kesempurnaan film adaptasi tersebut bukan disebabkan oleh kesesuaian dengan novel aslinya. Film adaptasi tersebut dinilai sukses dalam menangkap esensi, ruh, dan jiwa novel aslinya. Seperti pada novel Tujuh Misi rahasia Sophie karya Aditia Yudis dengan film berjudul Tujuh Misi Rahasia Sophie yang di sutradarai oleh Billy Christian.

Menurut Afri, dkk. (2014) film sebagai media komunikasi dalam menyampaikan informasi, pendidikan, dan hiburan adalah salah satu media visual yang memiliki jangkauan sangat luas bersifat terbuka yang meliputi berbagai usia dan lapisan masyarakat. Jadi film merupakan salah satu media audio visual yang dapat menyampaikan informasi pendidikan dan hiburan, sehingga penikmat film dapat menerima manfaat yang sesuai dengan penonton butuhkan. Film bisa ditempatkan dalam semua kalangan, seperti film Tujuh Misi Rahasia Sophie yang bisa dilihat oleh seorang remaja.

Ide tentang sastra bandingan dikemukakan oleh Sante Beuve dalam artikel yang terbit tahun 1868 (Damono, 2005: 14) Sastra bandingan merupakan salah satu dari sekian banyak pendekatan yang ada dalam ilmu sastra. Pendekatan sastra bandingan pertama kali muncul di Eropa awal abad ke-19. Dalam artikel tersebut dijelaskan bahwa pada awal abad ke-19 telah muncul studi sastra bandingan di Prancis. Sedangkan pengukuhan terhadap pendekatan perbandingan terjadi ketika jurnal Revue Litterature Comparee diterbitkan pertama kali pada tahun 1921.

Dalam psikologi, perilaku atau aktivitas yang ada pada individu atau organisme dianggap tidak muncul dengan sendirinya, tetapi sebagai akibat dari adanya stimulus atau rangsang yang mengenai individu atau organisme itu. Tujuan psikologi sastra untuk memahami aspek-aspek kejiwaan yang terkandung dalam suatu karya. Penggambaran cerita di dalam novel maupun film dapat menggambarkan kehidupan di dunia nyata, penggambaran tersebut bisa dilihat dari tingkah laku atau karakteristik tokoh-tokoh yang tercipta baik dari khayalan ataupun nyata. Sehingga, para penikmat cerita fiksi maupun film kerap tenggelam dalam cerita dan ikut terbawa emosi, seperti rasa sedih dan marah hingga membuat menangis. Karakter dalam sebuah cerita atau film memperlihatkan kehidupan sehari-hari setiap insan. Misalnya, bahagia, iri, sedih, kecewa dll. Beragam karakter tokoh yang dijadikan peran, bagi penonton ataupun pembaca memiliki pandangan secara psikologis atau emosional dalam menikmati cerita. Ada yang sedu sedan dan ada juga yang tidak merasakan emosi apa pun.

\section{METODE PENELITIAN}

Penelitian ini menggunakan metode kualitatif dengan hasil penelitian dideskripsikan. Metode ini dilakukan dengan cara mendeskripsikan fakta-fakta yang kemudian disusul dengan analisis (Ratna, 


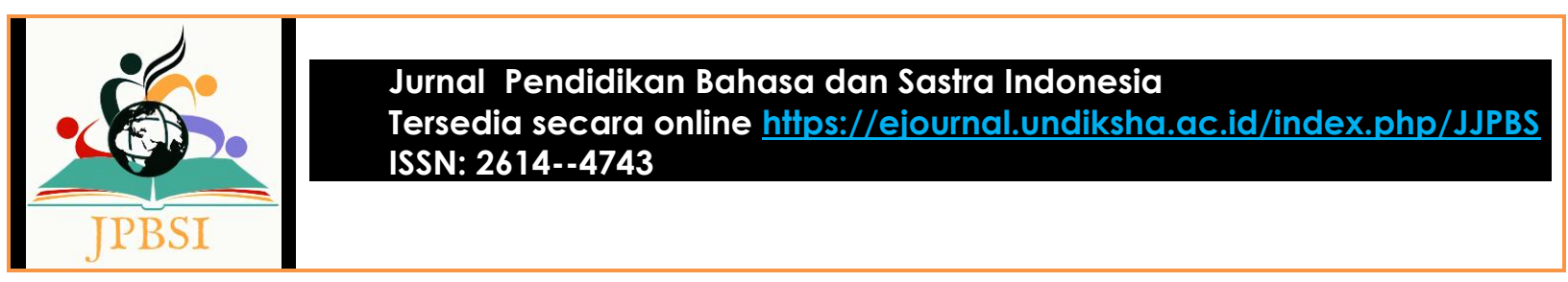

2015: 53). Moelong (2017: 11) menjelaskan penelitian kualitatif bersifat deskriptif artinya data yang dikumpulkan berupa kata-kata, gambar, dan bukan angka-angka. Penelitian akan memaparkan dan menjelaskan transformasi novel ke film Tujuh Misi Rahasia Sophie dengan menggunakan pendekatan psikologi sastra.

Sumber data penelitian adalah novel dan film Tujuh Misi Rahasia Sophie. Objek kajian membandingkan novel dan film Tujuh Misi Rahasia Sophie kemudian menemukan perbedaannya. Data diperoleh dengan cara menemukan perubahan-perubahan novel dan Film Tujuh Misi Rahasia Sophie. Teknik pengumpulan data menggunakan teknik simak dan catat juga teknik dokumentasi. Data-data yang diambil sebagai bahan dalam penelitian ini adalah novel Tujuh Misi Rahasia Sophie dan Film Tujuh Misi Rahasia Sophie.

Teknik analisis data pada penelitian ini menggunakan langkah-langkah seperti yang dikemukakan Miles and Huberman (dalam Sugiyono, 2018: 335). Jadi, teknik analisis data yang digunakan adalah model Miles and Hubermand, yaitu meliputi tiga komponen antaranya reduksi data, penyajian data, dan penarikan kesimpulan. Reduksi Data, berarti merangkum, memilih hal-hal pokok, memfokuskan pada hal-hal yang penting. Penyajian Data, Dapat dilakukan dengan menggunakan teks naratif, grafik, matrik, network dan chart. Conclusion drawing/Verification, merupakan penarikan kesimpulan yang dapat menjawab rumusan masalah. Teknik analisis data dilakukan dengan beberapa cara, yaitu melakukan pembacaan novel Tujuh Misi Rahasia Sophie, menandai bagian struktur alur, tokoh, dan latar yang terdapat dalam novel. Selanjutnya menonton film Tujuh Misi Rahasia Sophie dan mencatat struktur alur, tokoh, dan latar yang terdapat pada film. Data-data yang telah diperoleh dianalisis proses transformasi cerita dan aspek kejiwaan tokoh utama. Analisis data dalam penelitian kualitatif, dilakukan pada saat pengumpulan data berlangsung, yaitu dengan mengumpulkan informasiinformasi yang dibutuhkan seperti struktur cerita, perbedaan-perbedaan dalam novel dan film Tujuh Misi Rahasia Sophie.

\section{HASIL DAN PEMBAHASAN}

Di dalam novel Tujuh Misi Rahasia Sophie menggambarkan kisah Sophie dan Marko seorang remaja SMA, Sophie seorang gadis yang cantik, ceria dan selalu menebarkan sifat positifnya kepada orang lain dan ingin sekali merubah sifat temannya Marko yang memiliki perbedaan sifat 360 Derajat dari Sophie, Marko seorang pria yang, malas, acuh terhadap orang lain, dan tidak peduli terhadap sekitar. Tujuh Misi Rahasia Sophie menceritakan misi-misi Sophie untuk merubah Marko menjadi orang yang lebih baik. Novel Tujuh Misi Rahasia Sophie ini terdapat 18 Bab dan film Tujuh Misi Rahasia Sophie memiliki durasi film 94.38 menit. Terdapat beberapa perubahan antara novel kedalam film Tujuh Misi Rahasia Sophie berikut tabel struktur perbandingan perbedaan antara novel dan film Tujuh Misi Rahasia Sophie yaitu sebagai berikut.

Tabel 01 Perbandingan Novel dan Film

\begin{tabular}{|c|l|l|}
$\begin{array}{c}\text { Perbedaan antara } \\
\text { novel dan film }\end{array}$ & \multicolumn{1}{|c|}{ Pada Novel Tujuh Misi Rahasia Sophie } & \multicolumn{1}{c|}{ Pada Film Tujuh Misi Rahasia Sophie } \\
\hline 1. Alur & $\begin{array}{l}\text { Alur maju karena penulis menceritakan } \\
\text { kejadian dari awal hingga akhir cerita. }\end{array}$ & $\begin{array}{l}\text { Alur maju karena di dalam film menceritakan } \\
\text { bagaimana kejadian dari awal sampai akhir } \\
\text { cerita. }\end{array}$ \\
\hline \multirow{5}{*}{ Tokoh } & $\begin{array}{l}\text { Terdapat 13 orang tokoh di antaranya: } \\
\text { Sophie, Marko, Mama dan Papah Sophie, } \\
\text { Mama dan Papa Marko, Marsha, Livia, } \\
\text { Oma, Imel, Jenny, Mas Tarjo, dan Bian. }\end{array}$ & $\begin{array}{l}\text { Terdapat 17 tokoh yaitu: Sophie, Marko, } \\
\text { Parsha, Livia, Imel, Oma, Papa dan Mama } \text { Mama } \\
\text { Imel, Cowok Cupu, Mas Tarjo, Bian, Adik } \\
\text { Marko, dan 2 Orang Koki. } \\
\text { Terdapat penambahan 4 tokoh sedangkan } \\
\text { tokoh Jenia hanya terdapat dalam novel. }\end{array}$ \\
\hline
\end{tabular}




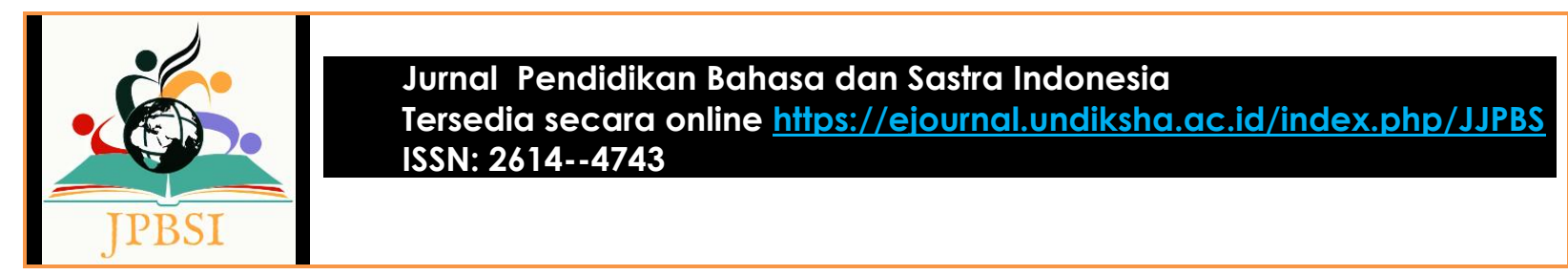

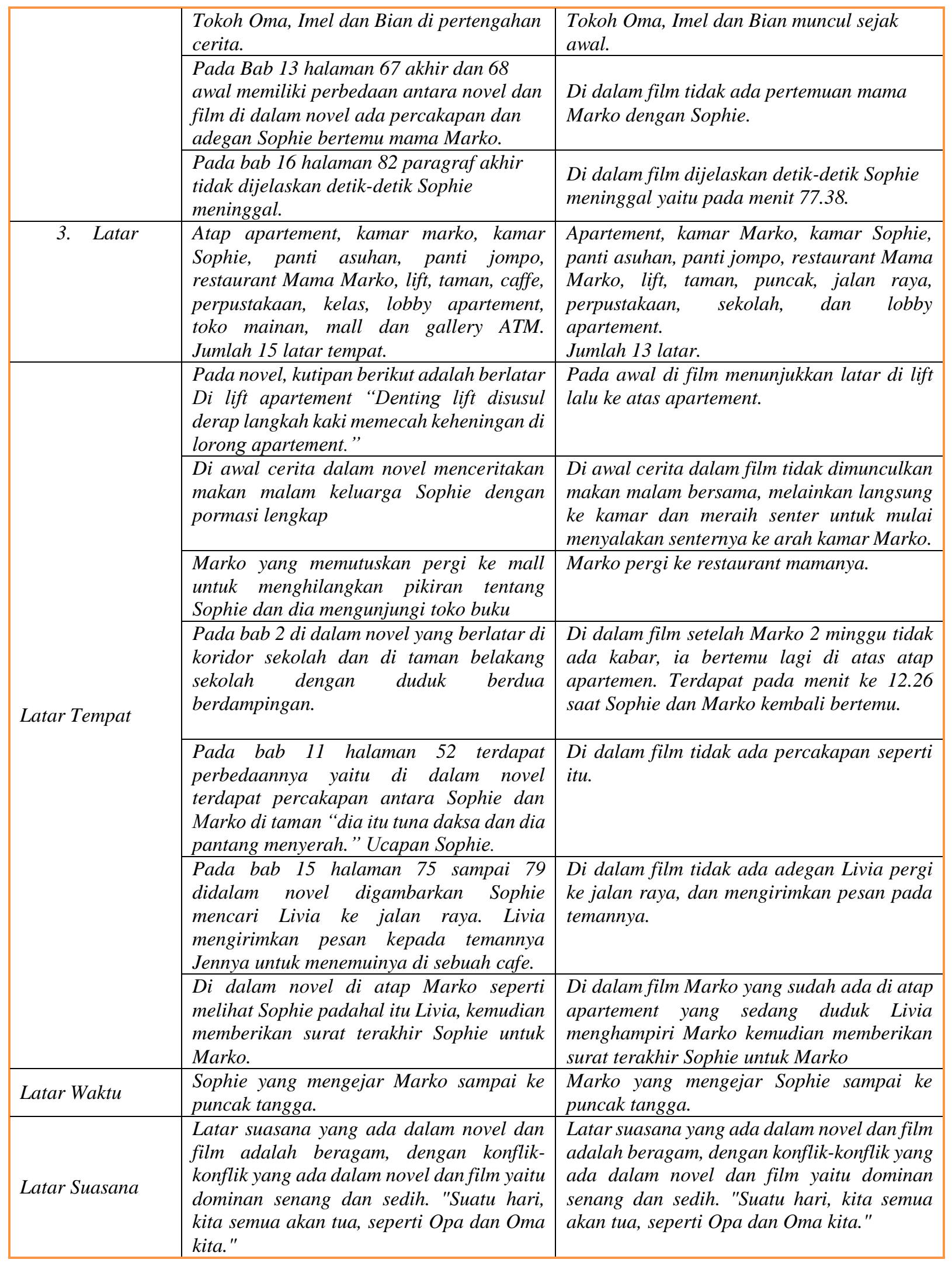




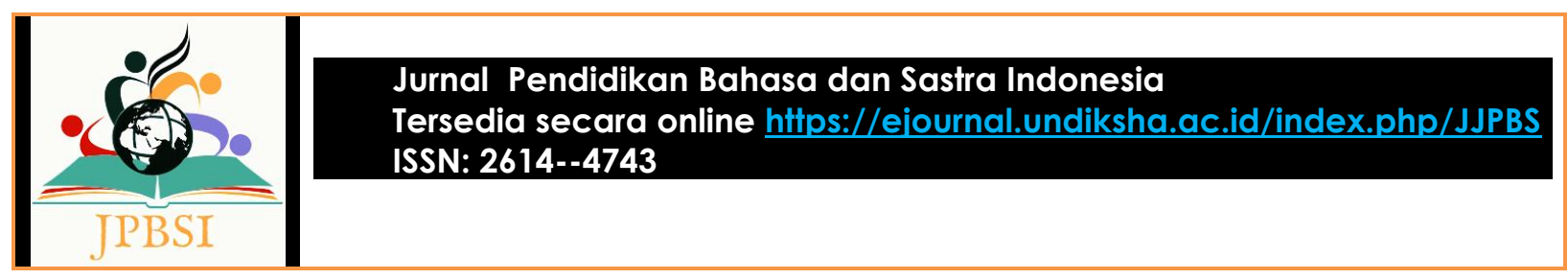

\begin{tabular}{|l|l|l|}
\hline & Kutipan di atas menunjukkan suasana & Kutipan di atas menunjukkan suasana \\
kesedihan ketika bersama Oma. Terima & kesedihan ketika bersama Oma. Terima \\
kasih, Marko," ujar Mama. Tersenyum. & kasih, Marko," ujar Mama. Tersenyum. \\
Marko membalas. Dia lupa kapan terakhir & Marko membalas. Dia lupa kapan terakhir \\
kalinya melihat mama tersenyum untuknya. & kalinya melihat mama tersenyum untuknya. \\
Hari ini, Marko mendapatkannya lagi. & Hari ini, Marko mendapatkannya lagi. \\
Kutipan di atas menunjukkan rasa senang & Kutipan di atas menunjukkan rasa senang \\
Mama Marko terhadap Marko. & mama Marko terhadap Marko. \\
\hline
\end{tabular}

Transformasi novel ke film terdapat penambahan, perubahan, pengurangan. Karena dalam transformasi novel ke dalam film haruslah memberikan variasi atau perbedaan yang hendaknya tidak merubah suatu karya yang telah diadaptasi tersebut. Ekranasi terdapat beberapa strategi kompetitif dikutip Dwight V, Swain dan Joye R, Swain oleh Simbolon (dalam Malida 2009) Menyebutkan tiga strategi untuk mengekranisasi novel ke film, yaitu mengikuti buku (novel), mengambil konflik-konflik penting, atau membuat cerita baru. Novel 7 Misi Rahasia Sophie ini terdapat 18 Bab cerita dan film 7 Misi Rahasia Sophie memiliki durasi film 94.38 menit.

Tabel 02 Proses Transformasi/penambahan, perubahan dan pengurangan

\begin{tabular}{|c|c|c|c|c|c|}
\hline No. & Deskripsi & $\begin{array}{l}\text { Bab/hlm. } \\
\text { Pada } \\
\text { novel }\end{array}$ & $\begin{array}{l}\text { Durasi } \\
\text { dalam } \\
\text { film }\end{array}$ & Perbedaan/persamaan & $\begin{array}{c}\text { Proses } \\
\text { transformasi/penambahan, } \\
\text { perubahan dan } \\
\text { pengurangan }\end{array}$ \\
\hline 1 & $\begin{array}{l}\text { Sophie dan Marko } \\
\text { bergegas untuk } \\
\text { menuju Rooftop }\end{array}$ & 1/hlm. 2-3 & 01.34 & $\begin{array}{lr}\text { Mengawali cerita, di dalam } \\
\text { novel digambarkan } \\
\text { keheningan di lorong } \\
\text { apartement dan } \\
\text { memanggil Sophie. Karenar } \\
\text { pintu apartment masih } \\
\text { tutup mereka mendaki } \\
\text { tangga darurat menuju } \\
\text { rooftop atau atap } \\
\text { apartement. } \\
\text { Sedangkandidalam film, di } \\
\text { awal cerita digambarkan } \\
\text { Sophie yang keluardarilift, } \\
\text { lalu Marko mengejar } \\
\text { Sophie dan di lorong } \\
\text { Marko hampir menabrak } \\
\text { Oma yang duduk di kursi } \\
\text { roda dan sedang di dorong } \\
\text { oleh Imel. Marko mengejar } \\
\text { Sophie melalui tangga } \\
\text { darurat sampai ke atas } \\
\text { apartement. }\end{array}$ & $\begin{array}{l}\text { Perubahan cerita dari } \\
\text { novel ke film. }\end{array}$ \\
\hline 2 & $\begin{array}{lr}\text { Padar saat } \\
\text { perdebatan kedua } \\
\text { adiknyar dan } \\
\text { makan malam. }\end{array}$ & $1 / h \operatorname{lm} .5$ & 04.02 & $\begin{array}{l}\text { Perdebatan itu berhenti } \\
\text { sebentar, digantikan music } \\
\text { rock, sampai Marsya tidak } \\
\text { tahan untuk protes. Ucap } \\
\text { Mama ke Livia ngalah dong } \\
\text { sama adeknya dengan apa } \\
\text { yang terdapat dalam film. } \\
\text { Diceritakan makan malam } \\
\text { kali ini dalam formasi }\end{array}$ & $\begin{array}{l}\text { Perubahan cerita dari } \\
\text { novel ke film. }\end{array}$ \\
\hline
\end{tabular}




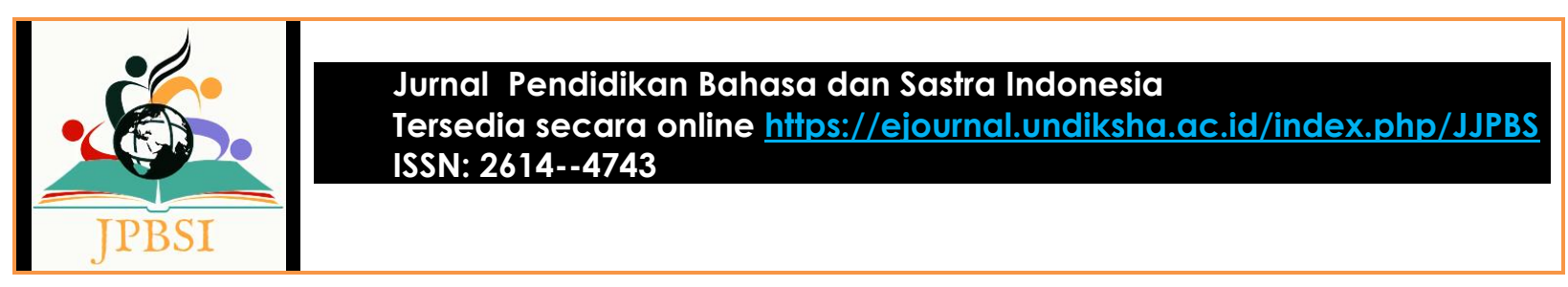

\begin{tabular}{|c|c|c|c|c|c|}
\hline & & & & $\begin{array}{l}\text { lengkap dan terdapat } \\
\text { percakapan serta senda } \\
\text { gurau antara mama, papa } \\
\text { dan kedua adiknya. Tetapi } \\
\text { di dalam film adegan } \\
\text { perdebatan kedua adiknya } \\
\text { itu terhenti ketika mama } \\
\text { mengucapkan Livia ngalah } \\
\text { dong sama adiknya, } \\
\text { selanjutnya makan malam } \\
\text { yang digambarkan } \\
\text { sutradara hanya sebagai } \\
\text { kesan makan malam dan } \\
\text { alunan musik. }\end{array}$ & \\
\hline 3 & $\begin{array}{l}\text { Marko terpaku } \\
\text { ditempatnya, } \\
\text { melihat Sophie } \\
\text { yang berlalu } \\
\text { hilang setelah ia } \\
\text { diam-diam } \\
\text { memvideokan } \\
\text { dengan handycam. } \\
\text { Marko melihat } \\
\text { Papa Marko. }\end{array}$ & $\begin{array}{ll}2 / h \operatorname{lm} . \quad 9- \\
11\end{array}$ & 10.21 & $\begin{array}{l}\text { Setelah Sophie } \\
\text { meninggalkan Marko di } \\
\text { atap apartement, setelah itu } \\
\text { Marko memutuskan pergi } \\
\text { ke mall dan menghilangkan } \\
\text { pikirannya tentang Sophie. } \\
\text { Di dalam novel } \\
\text { menceritakan Marko pergi } \\
\text { ke mall dan toko buku yang } \\
\text { biasa dikunjungi bersama } \\
\text { Sophie, lalu marko melihat } \\
\text { papa bersama keluarga } \\
\text { kecil yang tampak bahagia. } \\
\text { Sampai sesampainya di } \\
\text { apartement, mama melihat } \\
\text { Marko masuk ke ruangan } \\
\text { dan mengingatkan Marko } \\
\text { untuk main ke tempat papa. } \\
\text { Sedangkan pada film } \\
\text { Marko pergi ke restaurant } \\
\text { dan dinasihati oleh } \\
\text { Mamanya untuk jangan } \\
\text { lupa pergi main ke tempat } \\
\text { papa, lalu ia melihat papa } \\
\text { dan keluarga barunya. }\end{array}$ & $\begin{array}{l}\text { Perubahan cerita dari } \\
\text { novel ke film. }\end{array}$ \\
\hline 4 & $\begin{array}{l}\text { Mereka berdua } \\
\text { duduk di taman } \\
\text { belakang, }\end{array}$ & 4/hlm.14 & 13.01 & $\begin{array}{l}\text { Sophie bertemu Marko di } \\
\text { taman belakang, tetapi di } \\
\text { film Sophie bertemu Marko } \\
\text { di Atap apartement. }\end{array}$ & $\begin{array}{l}\text { Perubahan cerita dari } \\
\text { novel ke film. }\end{array}$ \\
\hline 5 & $\begin{array}{l}\text { Sophie dan Marko } \\
\text { menjalani misi ke } \\
\text { dua yaitu ke rumah } \\
\text { panti jompo } \\
\text { menggunakan } \\
\text { kostum kelinci dan } \\
\text { beruang. }\end{array}$ & 6/hlm. 24 & 22.48 & $\begin{array}{l}\text { Imel diceritakan dalam } \\
\text { novel pada saat Sophie } \\
\text { sakit perut dan Marko ingin } \\
\text { mengantarkannya, tetapi } \\
\text { Sophier menolaknya, } \\
\text { akhirnya mereka duduk di } \\
\text { sofa loby apartement dan } \\
\text { Sophie fokus ke handphone } \\
\text { sedangkan Marko } \\
\text { mendengarkan musik lewat } \\
\text { earphone. Sedangkan pada }\end{array}$ & $\begin{array}{l}\text { Penambahan cerita dari } \\
\text { novel ke film. }\end{array}$ \\
\hline
\end{tabular}




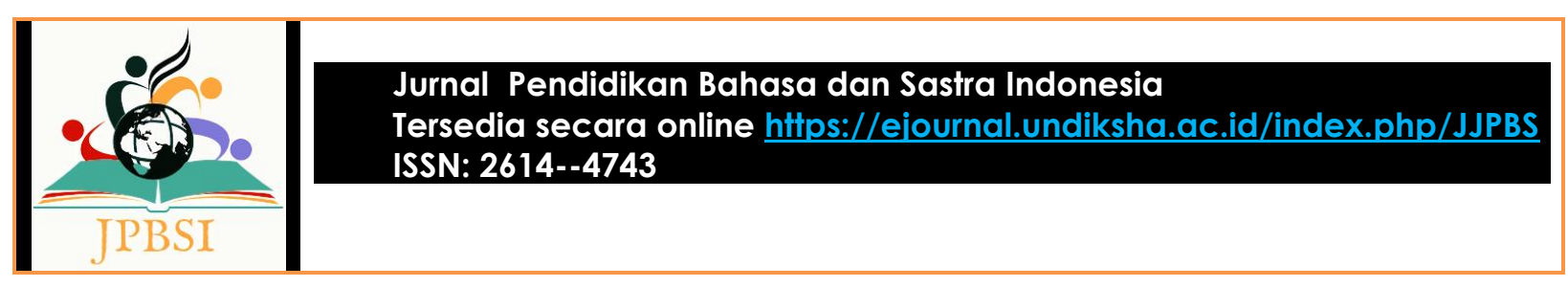

\begin{tabular}{|c|c|c|c|c|c|}
\hline & & & & $\begin{array}{l}\text { film tokoh Imel muncul } \\
\text { pada awal cerita dan saat } \\
\text { setelah misi ke dua selesai, } \\
\text { setelah itu Sophie dan } \\
\text { Marko akan masuk lift } \\
\text { tetapi bertemu tokoh Imel. } \\
\text { Di dalam film cerita lebih } \\
\text { di persingkat dan jelas } \\
\text { tetapi dengan tujuan yang } \\
\text { sama yang terdapat pada } \\
\text { novel. }\end{array}$ & \\
\hline 6 & $\begin{array}{l}\text { Sophie mencegat } \\
\text { penjual kopi } \\
\text { keliling dan } \\
\text { berpura-pura } \\
\text { menjadi reporter } \\
\text { TV Phieko. } \\
\text { Gerombolan } \\
\text { cewek-cewek } \\
\text { tertawa melihat } \\
\text { video Sophie dan } \\
\text { dua orang koki } \\
\text { laki-laki } \\
\text { mentertawakan } \\
\text { juga. }\end{array}$ & 10/hlm. 50 & 43.50 & $\begin{array}{l}\text { Di dalam film TV Bunny, } \\
\text { Sophie yang menghampiri } \\
\text { penjual kopi yang sedang } \\
\text { mangkal di taman dan } \\
\text { memberi bingkisan kursi } \\
\text { roda. Sedangkan di dalam } \\
\text { novel penjual kopi } \\
\text { berbicara "Saya nggak } \\
\text { ingin masuk TV kalau } \\
\text { hanya untuk dikasihani. } \\
\text { Saya nggak mau dikasihani } \\
\text { karena saya cacat". Di } \\
\text { dalam novel gerombolan } \\
\text { cewek-cewek tertawa } \\
\text { melihat video yang } \\
\text { berjudul misi rahasia } \\
\text { Sophie 4, yang berisikan } \\
\text { video penjual kopi. } \\
\text { Sedangkan di dalam film } \\
\text { dua orang koki laki-laki } \\
\text { mentertawakan video } \\
\text { Sophie yang berisikan } \\
\text { video penjual kopi. di } \\
\text { dalam novel yang berlatar } \\
\text { tempat di ATM dan pinggir } \\
\text { jalan Sophie mengambil } \\
\text { uang bersama Marko di } \\
\text { ATM Marko bertanya "Lo } \\
\text { ngambil uang banyak } \\
\text { banget buat apaan"?. }\end{array}$ & $\begin{array}{l}\text { Perubahan cerita dari } \\
\text { novel ke film. }\end{array}$ \\
\hline 7 & $\begin{array}{l}\text { Sophie kesakitan } \\
\text { karena } \\
\text { penyakitnya } \\
\text { kambuh lagi }\end{array}$ & 10/hlm. & 49.15 & $\begin{array}{l}\text { Sedangkan di dalam novel } \\
\text { Sophie kesakitan karena } \\
\text { penyakitnya kambuh lagi } \\
\text { dan terjadi dialog antara } \\
\text { Shopie dan Marko, Sophie } \\
\text { meringis. Meraih tangan } \\
\text { Marko. "He eh. Tapi nanti } \\
\text { sore, gue mau ngerayain } \\
\text { ulang tahun gue dipanti } \\
\text { asuhan. Lo ikut kan? Lo } \\
\text { tega biarin gue sendiri ke } \\
\text { sana? Gue lagi sakit perut } \\
\text { nih," katanya berjalan }\end{array}$ & $\begin{array}{l}\text { Perubahan cerita dari } \\
\text { novel ke film. }\end{array}$ \\
\hline
\end{tabular}




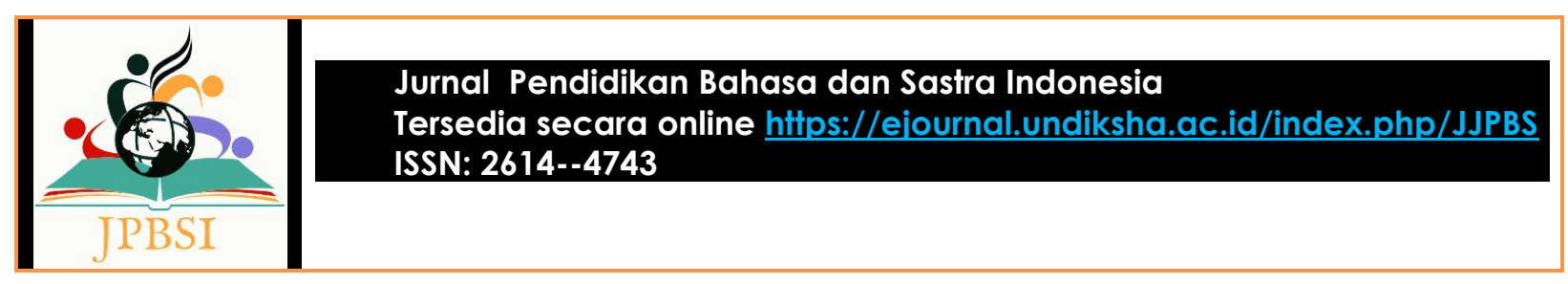

\begin{tabular}{|c|c|c|c|c|c|}
\hline & & & & $\begin{array}{l}\text { tertatih. Sedangkan di } \\
\text { dalam film yang berlatar } \\
\text { tempat dirumah Sophie. } \\
\text { Sophie yang sedang } \\
\text { menyiapkan peralatan } \\
\text { permainan untuk } \\
\text { merayakan ulang tahunnya } \\
\text { di panti asuhan dan tidak } \\
\text { ada dialog seperti yang ada } \\
\text { di novel. }\end{array}$ & \\
\hline 8 & $\begin{array}{lr}\text { Marko } & \text { yang } \\
\text { phobia } & \text { dengan } \\
\text { balon } & \text { lewat } \\
\text { flashback } & \text { ingatan } \\
\text { Marko, dan Marko } & \\
\text { berusaha } & \text { untuk } \\
\text { menahan rasa } \\
\text { phobianya. }\end{array}$ & 11/hlm. 53 & 53.05 & $\begin{array}{l}\text { Di dalam film tidak } \\
\text { dijelaskan alasan Marko } \\
\text { phobia dengan balon, di } \\
\text { dalam novel adegan Shopie } \\
\text { memberi Marko jas hujan } \\
\text { dan ada adegan Sophie dan } \\
\text { Marko menonton film } \\
\text { bersama-sama dengan } \\
\text { anak-anak di panti asuhan, } \\
\text { Sedangkan di dalam film } \\
\text { tidak ada adegan Sophie } \\
\text { dan Marko, Sophie } \\
\text { memberi jas hujan kepada } \\
\text { Marko dan tidak ada } \\
\text { adegan menonton film } \\
\text { bersama-sama dengan } \\
\text { anak-anak panti asuhan. } \\
\text { Sophie yang sedang } \\
\text { melihat rekaman video } \\
\text { yang diambil ketika } \\
\text { merayakan hari ulang } \\
\text { tahunnya di pantiasuhandi } \\
\text { dalam novel tidak ada } \\
\text { adegan Sophie yang } \\
\text { memutar video. }\end{array}$ & $\begin{array}{l}\text { Pengurangan cerita dari } \\
\text { novel ke film. }\end{array}$ \\
\hline 9 & $\begin{array}{lr}\text { Sophie } & \text { yang } \\
\text { bergegas } & \text { untuk } \\
\text { pergi menemui } \\
\text { Marko dan mama } \\
\text { Sophie mencegah } \\
\text { nyar karena } \\
\text { khawatir dengan } \\
\text { keadaannya }\end{array}$ & $\begin{array}{l}\text { 13/hlm. } \\
66-77\end{array}$ & 59.30 & $\begin{array}{l}\text { Di dalam novel Sophie } \\
\text { yang menyelinap masuk } \\
\text { kamar Marko, Marko } \\
\text { sedang menonton video di } \\
\text { laptop Sophie yang sudah } \\
\text { masuk bersama marko } \\
\text { untuk memilihkan baju } \\
\text { untukMarko kenakan untuk } \\
\text { misi Sophie. }\end{array}$ & $\begin{array}{l}\text { Pengurangan cerita dari } \\
\text { novel ke film. }\end{array}$ \\
\hline 10 & $\begin{array}{l}\text { Di dalam film } \\
\text { Sophie bertemu } \\
\text { mama Marko }\end{array}$ & $13 / \mathrm{hlm} 69$ & 63.18 & $\begin{array}{l}\text { Sophie bertemu mama } \\
\text { Marko di dalam film tidak } \\
\text { ada adegan mama Sophie } \\
\text { bertemu mama Marko. } \\
\text { Marko yang kesal dengan } \\
\text { Sophie karena Sophie } \\
\text { berusaha mendekatkan } \\
\text { Marko dan Imel, Marko } \\
\text { kesal tapi } \text { masih } \\
\text { melanjutkan } \\
\end{array}$ & $\begin{array}{l}\text { Pengurangan cerita dari } \\
\text { novel ke film. }\end{array}$ \\
\hline
\end{tabular}




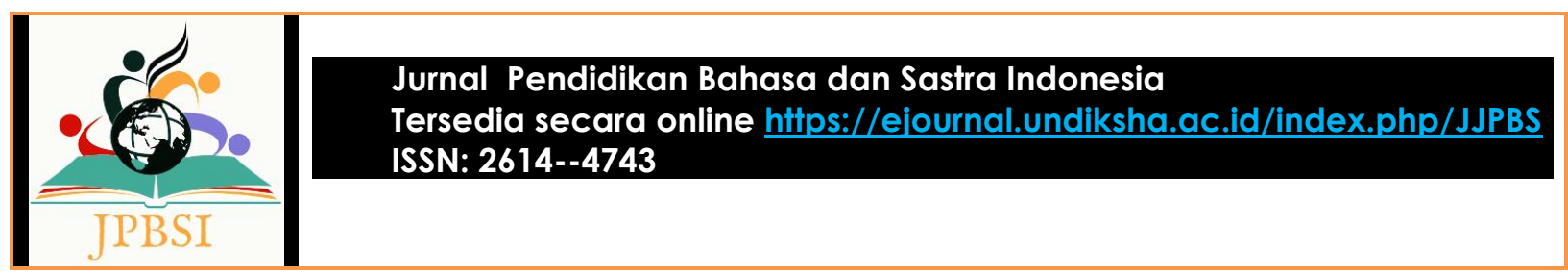

\begin{tabular}{|c|c|c|c|c|c|}
\hline & & & & $\begin{array}{l}\text { rahasianya Sophie, tidak } \\
\text { dijelaskan dialog antara } \\
\text { Marko dan Imel. }\end{array}$ & \\
\hline 11 & $\begin{array}{l}70 \text { Marko yang } \\
\text { kesal dengan } \\
\text { Sophie tapi masih } \\
\text { mau melanjutkan } \\
\text { misinyar untuk } \\
\text { makan malam } \\
\text { dengan Imel. }\end{array}$ & $13 / \mathrm{hlm} 70$ & 68.25 & $\begin{array}{l}\text { Marko yang kesal dengan } \\
\text { Sophie tapi masih mau } \\
\text { melanjutkan misinya untuk } \\
\text { makan malam dengan Imel. } \\
\text { Marko yang sengaja } \\
\text { memesan makanan dan } \\
\text { minuman yang mahal } \\
\text { Karena Sophie yang } \\
\text { membayar makanan } \\
\text { tersebut dan ada dialog } \\
\text { antara Marko dan Imel. } \\
\text { Pada film ada adegan } \\
\text { Mama Marko yang } \\
\text { mencicipi masakan koki di } \\
\text { dalam novel tidak ada } \\
\text { adegan seperti itu. }\end{array}$ & $\begin{array}{l}\text { Pengurangan cerita dari } \\
\text { novel ke film. }\end{array}$ \\
\hline 12 & $\begin{array}{lr}\text { Livia minggat dari } \\
\text { rumah } \\
\text { bertemu dan } \\
\text { jenny. }\end{array}$ & 14/hlm. 77 & 71.37 & $\begin{array}{l}\text { Livia minggat dari rumah } \\
\text { dan bertemu dengan jenny. } \\
\text { Pada film tidak ada adegan } \\
\text { Livia bertemu dengan } \\
\text { tokoh Jennya. Sophie yang } \\
\text { sedang ujian di sekolah } \\
\text { sedih melihat Marko yang } \\
\text { tak cuek. }\end{array}$ & $\begin{array}{l}\text { Perubahan cerita dari } \\
\text { novel ke film. }\end{array}$ \\
\hline 13 & $\begin{array}{l}\text { Di dalam novel } \\
\text { adegan } \\
\text { perpisahan mama } \\
\text { Sophie dan Sophie } \\
\text { tidak dijelaskan. }\end{array}$ & 16/hlm. 85 & 79.28 & $\begin{array}{l}\text { Marko pergi ke atap } \\
\text { apartement tempat biasa } \\
\text { Marko bertemu Sophie. } \\
\text { Diatap Marko seperti } \\
\text { melihat Sophie padahal itu } \\
\text { Livia, kemudian } \\
\text { memberikan surat terakhir } \\
\text { Sophie untuk Marko. Tetapi } \\
\text { di dalam film Marko yang } \\
\text { sudah adar diatap } \\
\text { apartement yang sedang } \\
\text { duduk Livia menghampiri } \\
\text { Markorkemudian } \\
\text { memberikan surat terakhir } \\
\text { Sophie untuk Marko. }\end{array}$ & $\begin{array}{l}\text { Perubahan cerita dari } \\
\text { novel ke film. }\end{array}$ \\
\hline
\end{tabular}

Karakter tokoh utama Sophie dan Marko sebagai seorang yang ceria, gambaran tersebut terdapat dalam novel dan film. Karakter psikologi tokoh Sophie yang menggambarkan ceria baik di kehidupan nyata ataupun saat menggambarkan dirinya untuk membuat video yang menginspirasi. Baik dengan orang terdekat ataupun orang lain. Dari kutipan novel dan tampilan di film, Sophie tetap menunjukkan kebahagiaannya. Karakteristik psikologi tokoh Sophie yang menggambarkan mengalah dengan kedua adiknya terdapat dalam novel dan film. Karakteristik psikologi tokoh Sophie yang menggambarkan rasa sedih ketika melihat penjual kopi keliling tidak memakai kursi roda yang telah diberikannya. Karakteristik psikologi tokoh utama Sophie yang bahagia ketika keluarganya memberikan kejutan ulang tahun untuk Sophie. Karakteristik psikologi tokoh Marko yang panik dan cemas ketika Sophie mengajaknya pergi ke tempat panti asuhan, Marko cemas karena dia tidak suka 


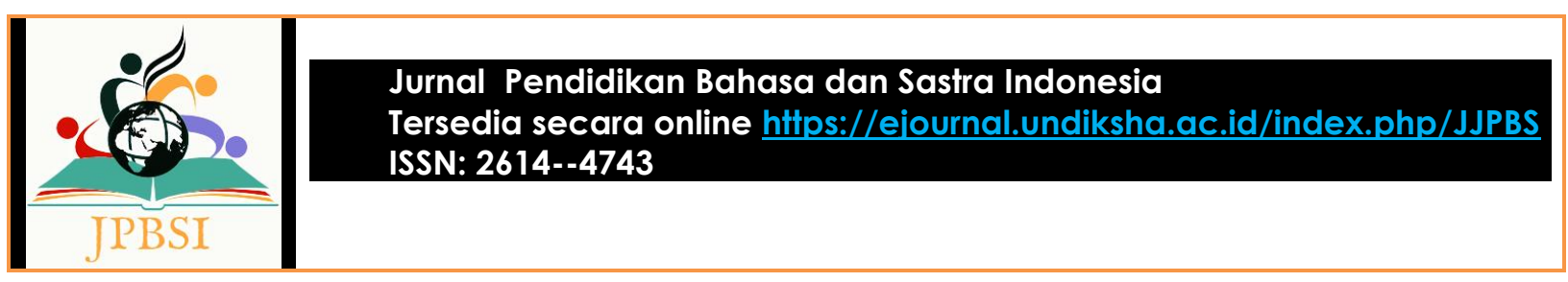

dengan anak kecil. Karakteristik psikologi tokoh utama Sophie yang senang ketika ulang tahunnya dirayakan di tempat panti asuhan. Karakteristik psikologi tokoh utama Marko yang ketakutan ketika dijahili oleh Shopie dengan mainan balon, karena Marko yang takut dengan balon. Karakteristik psikologi tokoh utama Shopie yang sedih ketika melihat rekaman video yang diambil ketika ulang tahunnya dirayakan di panti asuhan. Karakteristik psikologi tokoh utama Marko yang marah dan kesal pada Shopie karena berusaha mendekatkan Marko dengan Imel. Karakteristik psikologi tokoh utama Marko yang sedih sekaligus menyesal karena Shopie meninggal dunia dan Marko tidak bertemu dengan selama itu.

\section{PENUTUP}

Ada beberapa hal yang menjadi simpulan dalam penelitian ini. Pertama, perbandingan Struktur pada alur, tokoh, dan latar novel dan film Tujuh Misi Rahasia Sophie yaitu Ada beberapa hal yang menjadi simpulan dalam penelitian ini. Pertama, perbandingan Struktur pada alur, tokoh, dan latar novel dan film Tujuh Misi Rahasia Sophie yaitu dalam novel dan film di dalam novel terdapat 13 tokoh dan 15 latar tempat sedangkan di film terdapat 17 tokoh dan 13 latar tempat. Kedua, penambahan cerita dari novel kedalam film, terjadinya karena pembuat film dengan penulis novel Tujuh Misi Rahasia Sophie menyetujui. Seperti penambahan tokoh dalam film, penciutan dan pengurangan cerita dari novel Tujuh Misi Rahasia Sophie kedalam film Tujuh Misi Rahasia Sophie, sehingga terdapat perbedaan cerita antara novel dengan film, perubahan terjadi dengan bervariasi pada, latar dan tokoh. Novel dan film tujuh Tujuh Misi Rahasia Sophie memiliki perbedaan. Namun, tujuan, tema dan amanat novel ketika difilmkan masih tetap sama.

\section{DAFTAR PUSTAKA}

Damono Sapardi Djoko. 2005. Alih Wahana. Jakarta: Editum.

Mursih, Misbah Priagung Nursalim. (2019). Transformasi Novel Ke Film The Perfect Husband Karya Indah Riyana, Jurnal Sasindo Unpam, No 2 Vol 7 Tahun 2019.

Putri Nadia Afri, N. M. (2014). Transformasi Novel Ke Film Bidadari-Bidadari Surga: Kajian Ekranisasi, FBS Universitas Negeri Padang.

Ratna, Nyoman Kutha. 2015. Teori, Meode, dan Teknik Penelitian Sastra. Yogyakarta: Pustaka Pelajar. Reslyana, Malida. (2009). Transformasi Novel Pintu Terlarang Karya Sekar Ayu Asmara Ke Dalam Film (Kajian Sastra Bandingan), Bahtera Sastra: Antologi Bahasa dan Sastra Indonesia, 1 (3), 2009.

Siti Isnaniah. (2015). Ketika Cinta Bertasbih Transformasi Novel Ke Film, Kawistara No 1 (05).

Sugiyono. 2018. Metode Penelitian Pendidikan Pendekatan Kuantitatif, Kualitatif dan R\&D. Bandung: Alfabeta.

Suwardi. 2010. Sastra Bandingan metode, teori, dan aplikasi. Yogyakarta. FBS Universitas Negeri Yogyakarta.

Pt. Agus Artayasa, Gd. A. (2017). Perbandingan Novel Laskar Pelangi Karya Andrea Hirata Dengan Novel Dua Belas Pasang Mata Karya Sakae Tsuboi Serta Kontribusinya Bagi Pembelajaran Sastra Di Sma, Jurnal JPBSI, Universitas Pendidikan Ganesha, vol. 6 no 1 Tahun 2017.

Wiyatmi, 2011. Psikologi Sastra Teori dan Aplikasinya. Yogyakarta: Kanwa Publisher.

Yanis Erlina, A. B. (2016). Kajian Psikologi Sastra, Nilai Pendidikan, Dan Relevansinya Sebagai Materi Ajar Sastra Di SMA Pada Novel Ayah Menyayangi Tanpa Akhir Karya Kirana Kejora. Basastra. Jurnal Penelitian Bahasa Sastra Indonesia dan Pengajarannya. Vol 4. No. 1 Tahun 2016.

Copyright holder: ๑ Hidayat, P., Sudiana, I. N. \& Tantri, A. A. S. (2021)

Fist publication right: Jurnal Pendidikan Bahasa dan Sastra Indonesia Undiksha

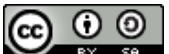

